\title{
Characterization of the spawning area of tuna species on the northern Tunisian coasts
}

\author{
Wael Koched ${ }^{1}$, Francisco Alemany ${ }^{2}$, Benmessaoud Rimel ${ }^{1}$, Abdallah Hattour ${ }^{3}$ \\ ${ }^{1}$ Institut National des Sciences et Technologies de la Mer (INSTM), BP 2060, Port de pêche la Goulette, Tunisia. \\ E-mail: kouched_wael@yahoo.fr \\ ${ }^{2}$ Instituto Español de Oceanografía, Muelle Pelaires S/N 07015, Palma de Mallorca, Illes Balears, Spain. \\ ${ }^{3}$ Institut National des Sciences et Technologies de la Mer (INSTM), 28 rue 2 mars 1934 - 2025, Salammbô, Tunisia.
}

\begin{abstract}
Summary: Early life stages of tuna species were investigated along the northern coasts of Tunisia in the summer of 2010, from 7 to 14 July. A total of 74 stations, distributed on a regular grid, were sampled. Larvae of five tuna species were identified: the Atlantic bluefin tuna, the bullet tuna, the Atlantic black skipjack, the Atlantic bonito and the albacore tuna. Larval distribution patterns show that Atlantic bluefin tuna and albacore tuna usually spawn in offshore oligotrophic waters and Atlantic black skipjack larvae on the continental shelf. The widespread distribution of bullet tuna larvae, suggests that it spawns on the entire continental shelf and over the shelf break. The results from the quotient analysis carried out to characterize the spawning habitat of each species, show that the input of recent surface Atlantic water (AW) masses play a key role in the spawning strategy of tuna species, particularly in the case of the Atlantic bluefin tuna, whose larvae were mainly caught in the mixed waters resulting from the interaction between recent AW and resident AW, as demonstrated by their preference for salinity values between 36.9 and 37.4 .
\end{abstract}

Keywords: tuna larvae; environmental variables; spatial distribution; spawning area; water masses; Mediterranean.

Caracterización del área de puesta de especies de túnidos en las costas del norte de Túnez

Resumen: Se investigaron las fases larvarias tempranas de especies de túnidos a lo largo de las costas del norte de Túnez, durante el verano de 2010, del 7 al 14 de julio. Se muestrearon un total de 74 estaciones, distribuidas en una malla regular. Se identificaron larvas de cinco especies: el atún rojo, la melva, la bacoreta, el bonito y el atún blanco. Los patrones de distribución de larvas muestran que el atún rojo y el atún blanco desovan generalmente en aguas oligotróficas alejadas de la costa. Por contra, la localización relativamente más costera de las larvas de bacoreta indica que esta especie se reproduce sobre la plataforma continental, mientras que la amplia distribución de las larvas de melva sugiere que esta especie desova a lo largo de toda la plataforma y el margen continental. Los resultados del análisis de proporcionalidad, llevado a cabo para caracterizar el hábitat de puesta de cada especie, muestran que la entrada de masas de agua superficial atlántica (AW) reciente juegan un papel clave en la estrategia de desove de las especies de túnidos, sobre todo en el caso del atún rojo, cuyas larvas fueron capturadas principalmente en las aguas de mezcla, resultantes de la interacción entre el AW reciente y la residente, como lo demuestra su preferencia por los valores de salinidad entre 36.9 y 37.4 .

Palabras clave: larvas de túnidos; variables ambientales; distribución espacial; área de puesta; masas de agua; Mediterráneo.

Citation/Como citar este artículo: Koched W., Alemany F., Rimel B., Hattour A. 2016. Characterization of the spawning area of tuna species on the northern Tunisian coasts. Sci. Mar. 80(2): 187-198. doi: http://dx.doi.org/10.3989/scimar.04332.27A

Editor: E. Massuti.

Received: August 3, 2015. Accepted: February 16, 2016. Published: April 4, 2016.

Copyright: 22016 CSIC. This is an open-access article distributed under the Creative Commons Attribution-Non Commercial Lisence (by-nc) Spain 3.0.

\section{INTRODUCTION}

Eight tuna species have been cited in Tunisian waters, five belonging to the Thunnini tribe, i.e Atlantic bluefin tuna (Thunnus thynnus thynnus [Linnaeus, 1758]), bullet tuna (Auxis rochei [Risso, 1810]), Atlantic black skipjack (Euthynnus alletteratus [Rafin- esque, 1810]), albacore (Thunnus alalunga [Bonnaterre, 1788]) and skipjack tuna (Katsuwonus pelamis [Linnaeus, 1758]), two belonging to the Sardini tribe, Atlantic bonito (Sarda sarda [Bloch, 1793]) and Plain Bonito (Orcynopsis unicolor [Geoffroy Saint-Hilaire, 1817]), and one belonging to the Scombermorini tribe, narrow-barred Spanish mackerel (Scomberomorus 
commerson [Lacepède, 1800]) (Ben Souissi et al. 2006, Bradai et al. 2004, Hattour 2000). However, albacore and skipjack tuna have been encountered only occasionally.

The above species inhabit tropical, subtropical and temperate seas around the world, and the majority of them undertake major feeding and spawning migrations (McKeown 1984, Fromentin and Powers 2005).

Tunisian waters are an important fishing area for tuna species, with total landings of 2922 tons in 2013 (DGPA 2013). Atlantic bluefin tuna accounts for the highest proportion of the total catch $(37.6 \%)$, followed by Atlantic bonito (24.5\%), Atlantic black skipjack $(21.7 \%)$ and bullet tuna $(16.15 \%)$. In this region tuna species have been mainly exploited by purse seiners, but many other types of fishing gears are used, such as surface longlines, light fishing, gill nets and pelagic trawls. Tuna traps, which previously constituted the major gear for catching tuna, have been abandoned since 2003 (Hattour 2007).

Large pelagic fishes are among the most important fishery resources in the world, in terms of both economic value and volume of landings, since according to FAO statistics skipjack was the third most fished species in the world in 2012, with almost 2.7 million tons.

In the Mediterranean region Atlantic bluefin tuna is the most valuable species due to its high price, which has led to an increase in fishing pressure on this species during the last few decades (Hattour 2000), particularly after the expansion of Atlantic bluefin tuna farming activities in the Mediterranean Sea since 1997 (Miyake et al. 2003).

The development of this practice has further contributed to the misreporting of catches of the eastern stock, which make it difficult to control captures and therefore to perform a reliable stock evaluation and comply with the total allowable catch (TAC) fixed by the International Commission for the Conservation of Atlantic Tunas (ICCAT) (ICCAT 2009). This has led to an overexploitation of this stock, which has declined rapidly, as shown by the evaluations carried out by the ICCAT Standing Committee of Research and Statistics (SCRS) in the late 20th century and the first decade of the 21 st century. These evaluations indicate that the stock biomass in 2009 was less than approximately $40 \%$ of that estimated in the early 1970s (ICCAT 2009). To ensure the sustainability of this resource, the scientific committee of ICCAT recommended improving knowledge of its reproductive biology and ecology to implement more suitable and effective management plans. To prevent the collapse of the stock, a strict protective measures as an increase in the minimum legal sizes and TACs, have been implemented since 2007 under the framework of a recovery plan (ICCAT 2010), and according to the latest evaluations they have resulted in a recovery of stock biomass (ICCAT 2014). Nevertheless, sound scientific knowledge on some of the processes affecting population dynamics is still required for the design and implementation of medium-and long-term management plans aimed at guaranteeing the sustainability of the stock under changing environmental scenarios. Thus, in compliance with IC-
CAT recommendations, taking into account that early life planktonic stages constitute a critical period that largely determines the recruitment success of teleost fishes (Hsieh et al. 2006), the National Institute of Marine Science and Technology (INSTM) has initiated a research programme on tuna larvae ecology in Tunisian waters, aiming to identify the tuna spawning grounds, still unknown in this region, and the environmental influence on their location and on larval survival, which should constitute the basis for the design of quantitative surveys to calculate larval indices for spawning stock biomass estimation.

Within this framework, two areas have been investigated up to now: the north-eastern coasts and the Gulf of Gabes (Koched et al. 2012, 2013). These studies have demonstrated that Tunisian waters constitute a potential spawning area for several tuna species, like other Mediterranean areas, such as the Balearic archipelago (Garcia et al. 2003, 2005, Alemany et al. 2010, Piccinetti et al. 2013), the Tyrrhenian Sea (Cavallaro et al. 1997, Piccinetti et al. 1997), the Ionian Sea (Tsuji et al. 1997, Santamaria et al. 2000, Piccinetti et al. 2013) and the eastern Mediterranean (Somarakis et al. 2011, Oray and Karakulak 2005, Isari et al. 2008).

The main aim of this paper is to describe the spatial distribution of tuna larvae, characterizing the as yet unexplored tuna spawning areas on the northern coasts of Tunisia, in order to complement the tuna larval ecology studies in Tunisian waters.

\section{MATERIALS AND METHODS}

\section{Study area}

This study was carried out on the northern coasts of Tunisia (Fig. 1). This area is located in the central Mediterranean Sea, near the Sicily strait in the northwest and the Sardinia channel in the northeast, where the water mass exchange between the western and the eastern basins of the Mediterranean takes place (Astraldi et al. 1998).

The northern coasts of Tunisia are characterized by rocky bottoms, unlike the gulf of Tunis, which is mainly a muddy and sandy bottom area (Ayari and Afli 2003).

\section{Sampling methods}

A multidisciplinary tuna larvae survey was carried out on the northern coast of Tunisia from 7 to 14 July 2010. Samples were taken over a regular grid of 74 stations $(10 \times 10$ nautical miles equidistant). Temperature, salinity and turbidity were measured at the surface for each station, by means of a WTW probe. Surface water samples were filtered through Whatman GF/C filters and kept frozen at $-20^{\circ} \mathrm{C}$ until analysis for chlorophyll $a$ determination, whereas surface samples for dissolved inorganic nitrogen (nitrite: $\mathrm{NO}_{2}^{-}$, nitrate: $\mathrm{NO}_{3}^{-}$, ammonium: $\left.\mathrm{NH}_{4}{ }^{+}\right)$and orthophosphate $\left(\mathrm{PO}_{4}^{3-}\right)$ were conserved at $-20^{\circ} \mathrm{C}$.

Tuna larvae were sampled with a Bongo net of 60 $\mathrm{cm}$ mouth diameter, fitted with 335 and $505 \mu \mathrm{m}$ mesh 

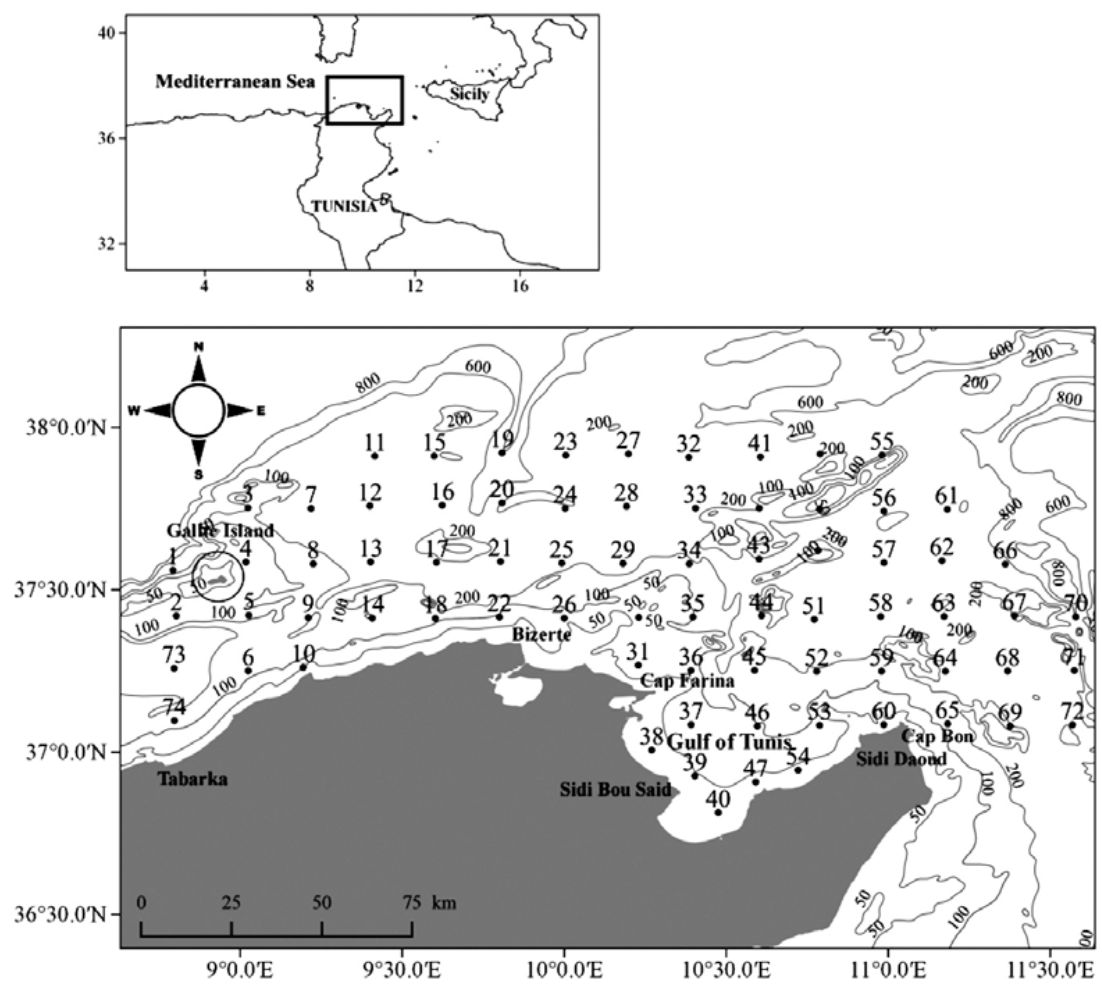

Fig. 1. - Location of sampling stations.

nets, in oblique tows. The average speed of the vessel was 2 knots, and the maximum depth sampled was 30 $\mathrm{m}$, covering the depth range in which tuna larvae are usually found (Morote et al. 2008, Satoh 2010). The average duration of each haul was 15 minutes, and the sampled larvae were initially conserved in $4 \%$ sea water borax-buffered formalin and preserved in ethanol after identification.

Zooplankton was sampled by means of a smaller plankton net with a $25 \mathrm{~cm}$ mouth, attached to the Bongo net and fitted with a $150 \mu \mathrm{m}$ mesh. Zooplankton samples were preserved frozen at $-20^{\circ} \mathrm{C}$. Hydro-Bios flowmeters were fitted to each net's mouth to estimate the volume of filtered water.

\section{Laboratory analysis}

To measure chlorophyll $a, 12 \mathrm{ml}$ of acetone (90\%) was added on each filter. This filter was later sonicated and centrifuged. After centrifuging, optical density was measured before and after acidification by a spectrophotometer. The concentration was calculated using the equation proposed by Lorenzen (1967):

$$
\operatorname{Chl} a\left(\mathrm{mg} \mathrm{m}^{-3}\right)=\frac{20.7 \times(E 1-E 2) \times v}{L \times V}
$$

where $E 1$ is the absorbance before acidification, $E 2$ the absorbance after acidification, $L$ the optical path in $\mathrm{cm}, V$ the volume filtered in litres and $v$ the volume of acetone added in ml. Nutrient salts were analysed with an automatic Bran and Luebbe type 3 analyser. Concentrations were determined colorimetrically according to Grasshoff (1983).
Fish larvae were sorted and identified under a binocular microscope, then preserved in ethanol. Tuna larvae were identified according to the taxonomic descriptions by Yabe et al. (1966), Dicenta (1975) and Alemany (1997), and standardized to numbers relative to $10 \mathrm{~m}^{2}$ of sea surface area.

Zooplankton dry weight was obtained following the methodology of Lovegrove (1966). This method consists in drying zooplankton samples in an electric oven at a temperature of $60^{\circ} \mathrm{C}$ for $72 \mathrm{~h}$. The value of zooplankton dry weight was standardized to $\mathrm{mg} \mathrm{m}^{-3}$.

\section{Data analysis}

Relations among environmental variables were investigated through principal component analysis (PCA) (Dolédec and Chessel 1989). Data were log $(\mathrm{x}+1)$ transformed in order to stabilize the variance (Frontier 1973). To establish the resemblance among the prospected stations, a hierarchical agglomerative clustering (Lebart et al. 1982) was carried out using the Euclidean distance coupled with group average linkage. The crossing was chosen to obtain groups with similar environmental conditions (temperature, salinity, chlorophyll $a$ and depth)

The PCA and cluster analysis were performed, respectively, with the XLSTAT (Ter Braak 1986) and PRIMER 6.1.6 packages (Clarke and Gorley 2006). Spearman correlations between variables were calculated using STATISTICA Software.

The spawning habitat preferences of the three most abundant species (Atlantic bluefin tuna, bullet tuna and Atlantic black skipjack) were characterized in terms 

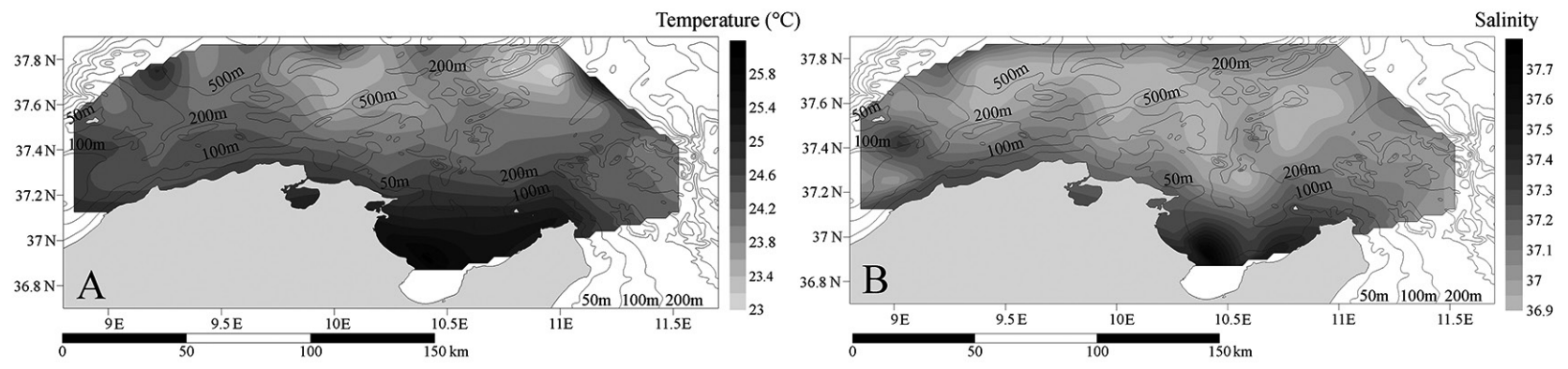

Fig. 2. - Horizontal distribution of sea surface temperature (A) and salinity (B).
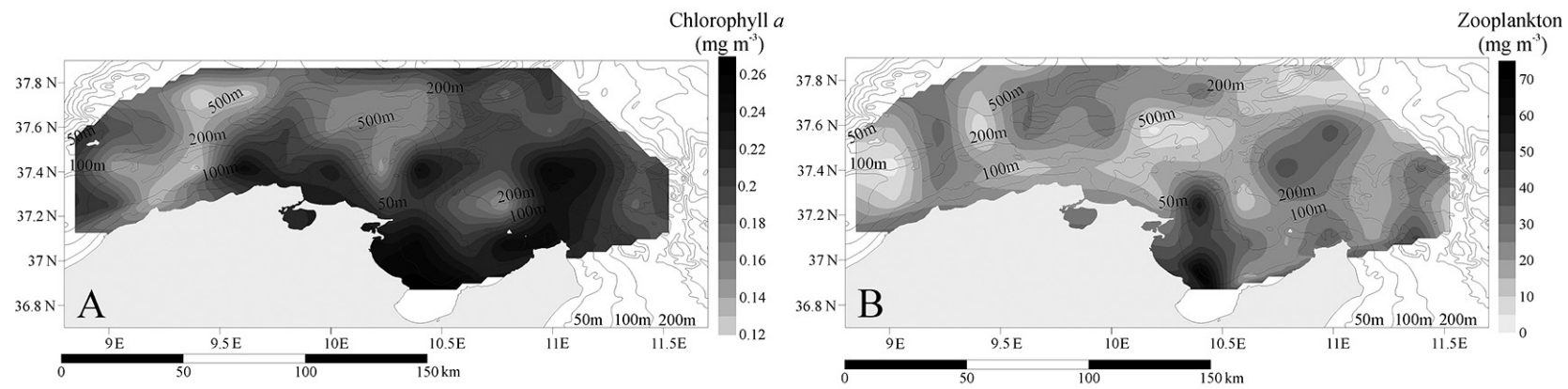

Fig. 3. - Superficial distribution of chlorophyll $a$ (A) and of dry weight zooplankton biomass (B).

of the environmental covariates recorded during this survey, i.e. temperature, salinity, zooplankton biomass, chlorophyll $a$ concentration and depth, using the Quotient analysis method (Twatwa et al. 2005):

$$
Q_{i}=\frac{A_{i} \sum_{i} A_{i}}{N_{i} \sum_{i} N_{i}}
$$

where $A_{i}$ is total larvae abundance per class $i$ (defined range of values in a given variable) and $N_{i}$ denotes total number of stations in the same class. Quotient values reflect preference $\left(Q_{i}>1\right)$ or unsuitability $\left(Q_{i}<1\right)$ for a particular environmental variable class.

\section{RESULTS}

\section{Environmental variables}

Sea surface temperature (SST) over the study area ranged from $23^{\circ} \mathrm{C}$ to $26.4^{\circ} \mathrm{C}$, with an average of $24.55 \pm 0.72^{\circ} \mathrm{C}(\mathrm{SD})$. The highest values were recorded in the gulf of Tunis, near the coast. A clear decreasing gradient was observed from the coast to offshore waters (Fig. 2A). The mean surface temperature calculated for inshore waters, where depths do not exceed $150 \mathrm{~m}$, was $25.6 \pm 0.45^{\circ} \mathrm{C}$ (SD) and that for offshore waters, where depths are greater than $150 \mathrm{~m}$ depth, was $23.8 \pm 0.34^{\circ} \mathrm{C}$ (SD).
The study area was dominated by relatively lowsalinity waters of recent Atlantic origin, not exceeding 37.3. The highest salinity values, between 37.6 and 37.8 , were recorded at the coastal stations of the gulf of Tunis (Fig. 2B). Sea surface salinity and surface temperature showed the same spatial trends, as indicated by their high and positive spatial correlation $(r=0.84$, $\mathrm{p}<0.001$ ) (Table. 1).

Surface chlorophyll a concentration and zooplankton biomass showed decreasing tendencies from coastal to offshore waters (Fig. 3A, B). This preferential association with shallow waters was confirmed by the negative spatial correlations between these two factors and depth, $\mathrm{r}_{\text {zooplankton/depth }}=-0.7 ; \mathrm{p}<0.001$ and $\mathrm{r}_{\text {chl } a / \text { depth }}=-0.62 ; \mathrm{p}<0.001$ (Table. 1). Sea surface chlorophyll $a$ concentration varied from 0.11 to $0.27 \mathrm{mg}$ $\mathrm{m}^{-3}$ (mean $\left.=0.204 \pm 0.039 \mathrm{mg} \mathrm{m}^{-3}(\mathrm{SD})\right)$. The highest concentrations were found in the neighbourhood of Sidi Daoud.

Horizontal variation of zooplankton biomass was relatively high, with differences between maximum and minimum values of $75 \mathrm{mg} \mathrm{m}^{-3}$. Average biomass value was $24 \pm 16 \mathrm{mg} \mathrm{m}^{-3}$ (SD). The maximum biomass value was recorded between Sidi Bou Saïd and Cap Farina.

Dissolved inorganic nitrogen (DIN) and orthophosphate concentrations were higher near the coast.

Table 1. - Spearman correlation matrix for environmental variables (ns $\mathrm{p}>0.05, * \mathrm{p}<0.05, * * \mathrm{p}<0.01, * * * \mathrm{p}<0.001$ ).

\begin{tabular}{|c|c|c|c|c|c|c|}
\hline & Temperature & Salinity & Turbidity & Depth & Chlorophyll $a$ & Zooplankton \\
\hline Temperature & 1 & & & & & \\
\hline Salinity & $0.84 * * *$ & 1 & & & & \\
\hline Turbidity & $0.49 * * *$ & $0.45 * *$ & 1 & & & \\
\hline Depth & $-0.68 * * *$ & $-0.63 * * *$ & $-0.64 * * *$ & 1 & & \\
\hline Chlorophyll $a$ & $0.63 * * *$ & $0.71 * * *$ & $0.67 * * *$ & $-0.62 * * *$ & 1 & \\
\hline Zooplankton & $0.69 * * *$ & $0.56^{* * *}$ & $0.51 * * *$ & $-0.7 * * *$ & $0.58 * * *$ & 1 \\
\hline
\end{tabular}




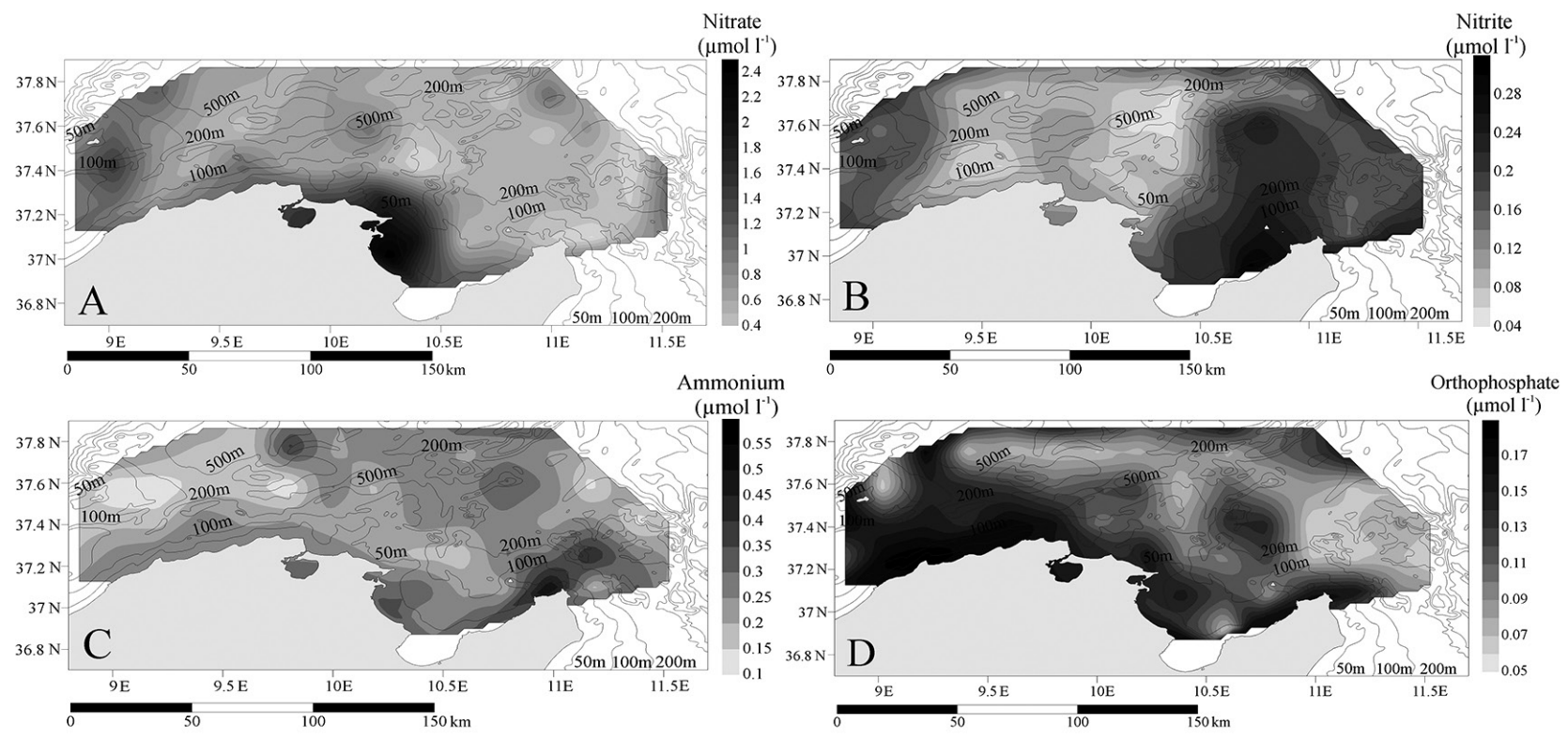

Fig. 4. - Spatial distribution of dissolved inorganic nitrogen (nitrate (A), nitrite (B), ammonium (C)) and orthophosphate (D).

Nitrate concentrations ranged between 0.46 and 2.5 $\mu \mathrm{mol} \mathrm{l}^{-1}\left(\right.$ mean $\left.=1.05 \pm 0.48 \mu \mathrm{mol} \mathrm{l^{-1 }}(\mathrm{SD})\right)$, with maximum concentrations recorded near Cap Farina (Fig. 4A), whereas the highest nitrite $\left(0.3 \mu \mathrm{mol} \mathrm{l}^{-1}\right)$ and ammonium $\left(0.58 \mu \mathrm{mol} \mathrm{l}^{-1}\right)$ concentrations were recorded near Cap Bon. Average values throughout the study area were $0.16 \pm 0.06 \mu \mathrm{mol} \mathrm{l}^{-1}(\mathrm{SD})$ and $0.25 \pm 0.08 \mu \mathrm{mol} \mathrm{l}^{-1}(\mathrm{SD})$, respectively (Fig. 4B, C). Orthophosphate concentrations varied from 0.05 to $0.2 \mu \mathrm{mol} \mathrm{l}^{-1}$. The average value was $0.11 \pm 0.04 \mathrm{umol} \mathrm{l}^{-1}(\mathrm{SD})$. The higher concentrations, between 0.15 and $0.2 \mu \mathrm{mol} \mathrm{l}^{-1}$, were found at the coastal stations, and the rest of the study area was dominated by moderate and low values $\left(<0.12 \mu \mathrm{mol} \mathrm{l}^{-1}\right)$ (Fig. 4D).

The results of PCA discriminated two groups: group A composed of chlorophyll $a$ and nutrient salts

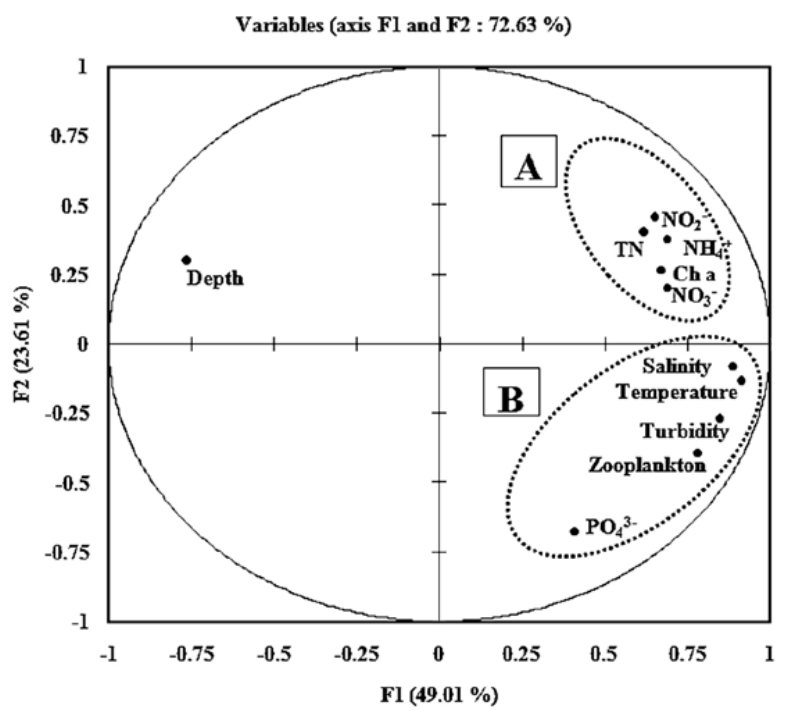

Fig. 5. - Principal component analysis (PCA) of different environmental variables, physical (temperature, salinity, turbidity), biological (chlorophyll $a$, zooplankton biomass) and chemical (TN, $\mathrm{NO}_{2}^{-}$, $\mathrm{NO}_{3}{ }^{-}, \mathrm{NH}_{4}{ }^{+}, \mathrm{PO}_{4}{ }^{3-}$ ) on the north coasts of Tunisia. (nitrite, nitrate, ammonium and total nitrogen); and group B composed of temperature, salinity, turbidity, orthophosphate and zooplankton biomass (Fig. 5). Variables belonging to group A were positively correlated with each other, as were the factors belonging to group B. Furthermore, all environmental variables that belonged to groups $\mathrm{A}$ and $\mathrm{B}$ showed an inverse relationship with depth.

The dendrogram from cluster analysis (Fig. 6) shows three main groups (A, B and C). Cluster A groups the neritic stations mostly located near the coast and in the gulf of Tunis. Stations belonging to this group were characterized by relatively hot (mean $=25.3 \pm 0.57^{\circ} \mathrm{C}$ $[\mathrm{SD}])$ and saline water $($ mean $=37.35 \pm 0.23[\mathrm{SD}])$ and also by low depth (mean $=92 \pm 74.1 \mathrm{~m}[\mathrm{SD}]$ ), with high zooplankton biomass and chlorophyll $a$ concentrations. Cluster B clumped together intermediate and oceanic stations (Fig. 7), mainly located in the eastern part of the study area. Most of them have a moderate depth (mean=205.6 $\pm 73.93 \mathrm{~m}[\mathrm{SD}]$ ). On the other hand, clus-

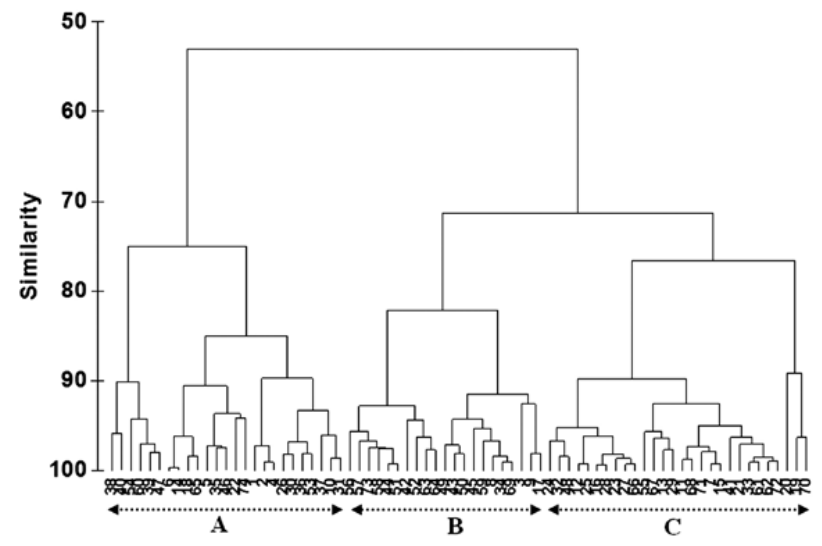

Fig. 6. - Dendrogram based on the Euclidean distance between the sampling stations based on the considered environmental factors: temperature, salinity, chlorophyll $a$, zooplankton biomass and depth. 


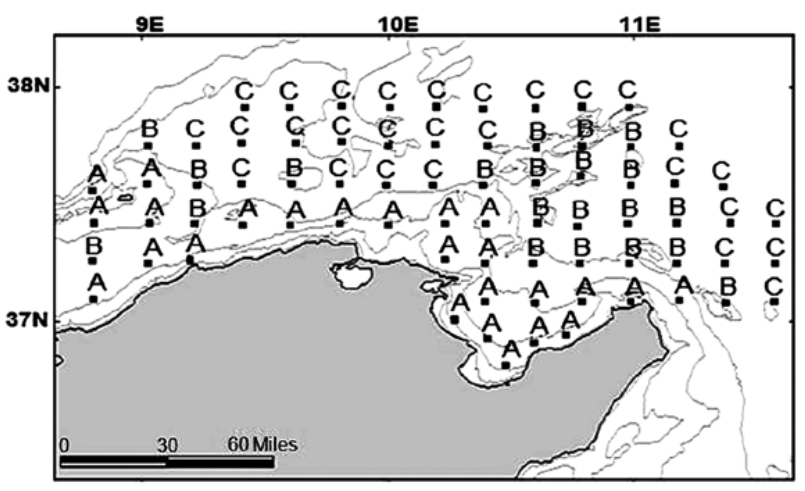

Fig. 7. - Spatial distribution of station clusters defined by the HAC analysis (Fig. 6).

ter C grouped only oceanic stations, characterized by high depths (mean $=433 \pm 134 \mathrm{~m}(\mathrm{SD}))$ and colder water, with an average of $24 \pm 0.4^{\circ} \mathrm{C}(\mathrm{SD})$.

\section{Larval abundance and distribution}

Larvae of five tuna species (Thunnus thynnus, Auxis rochei, Euthynnus alletteratus, Thunnus alalunga and Sarda sarda) were identified. Tuna larvae appeared in $88 \%$ of sampled stations.
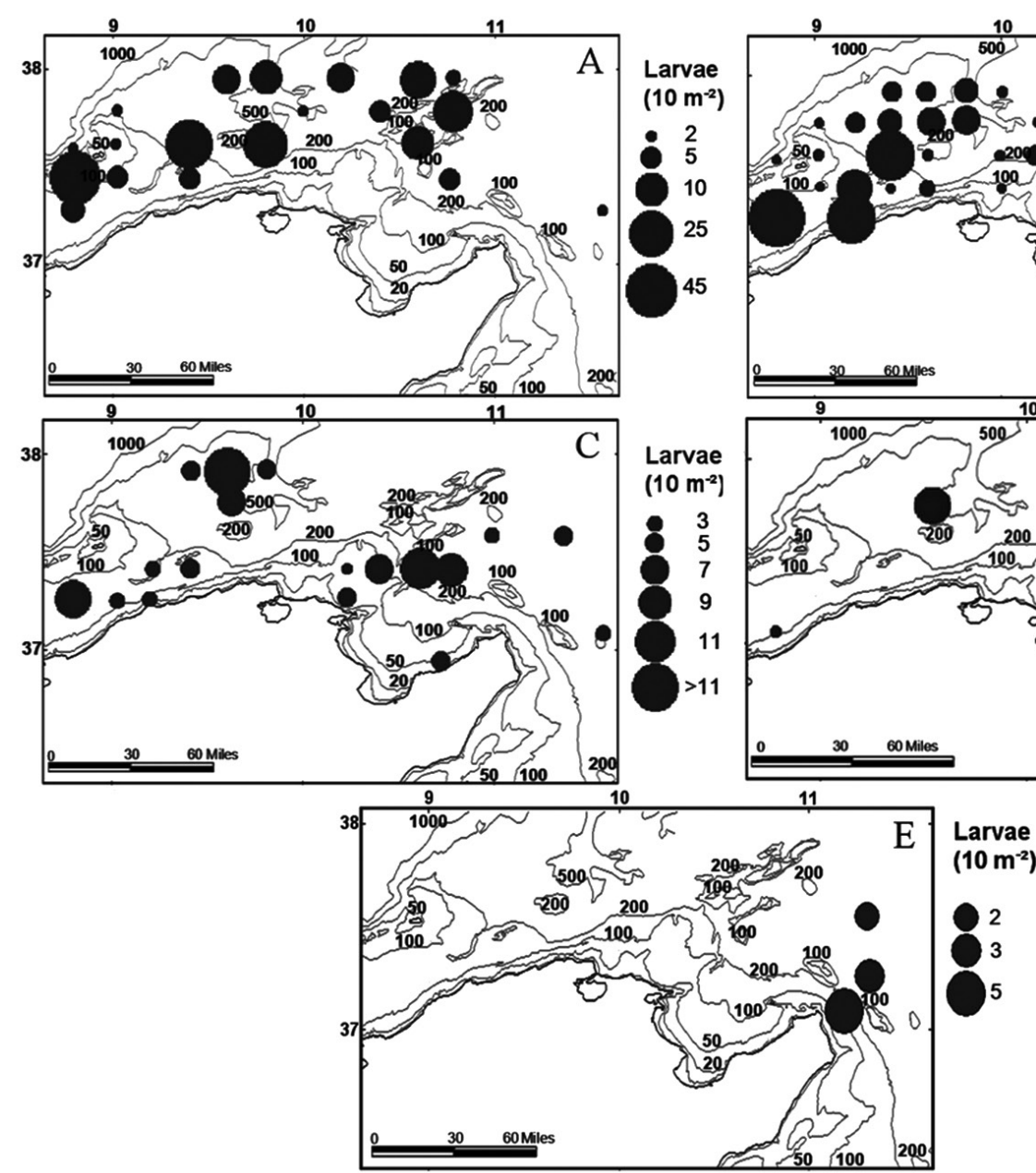

Tuna larval abundance varied between 1.5 and 251 larvae $/ 10 \mathrm{~m}^{2}$, with average values at the positive stations of $17.14 \pm 30.69$ larvae $/ 10 \mathrm{~m}^{2}(\mathrm{SD})$. Bullet tuna, Atlantic bluefin tuna and Atlantic black skipjack were, in this order, the three most abundant species among the sampled tuna larvae, with $84 \%, 11 \%$ and $3.9 \%$ of total tuna larvae abundance, respectively.

Bullet tuna larvae showed the widest distribution over the survey area, being found at almost $80 \%$ of the sampled stations (Fig. 8B). Their abundance varied from 1.5 to 235 larvae $/ 10 \mathrm{~m}^{2}$, with average values, in the positive stations, of $25.3 \pm 38.2$ larvae $/ 10 \mathrm{~m}^{2}(\mathrm{SD})$. The higher concentrations (between 110 and 235 larvae/10 $\mathrm{m}^{2}$ ) were found in the western part of the study area, mainly near the coast. The maximum abundance was recorded between Tabarka and Galite Island. In the gulf of Tunis, bullet tuna larvae were present at only three stations, with low abundances not exceeding 15 larvae $/ 10 \mathrm{~m}^{2}$.

Atlantic bluefin tuna larvae appeared at $27 \%$ of the prospected stations, mainly located in the intermediate and offshore part of the study area (Fig. 8A). In the gulf of Tunis the abundances were null, whereas the peak abundance $\left(45\right.$ larvae $/ 10 \mathrm{~m}^{2}$ ) was recorded near Galite Island.

Larvae of the Atlantic black skipjack were mostly collected at the inshore stations located near the coast
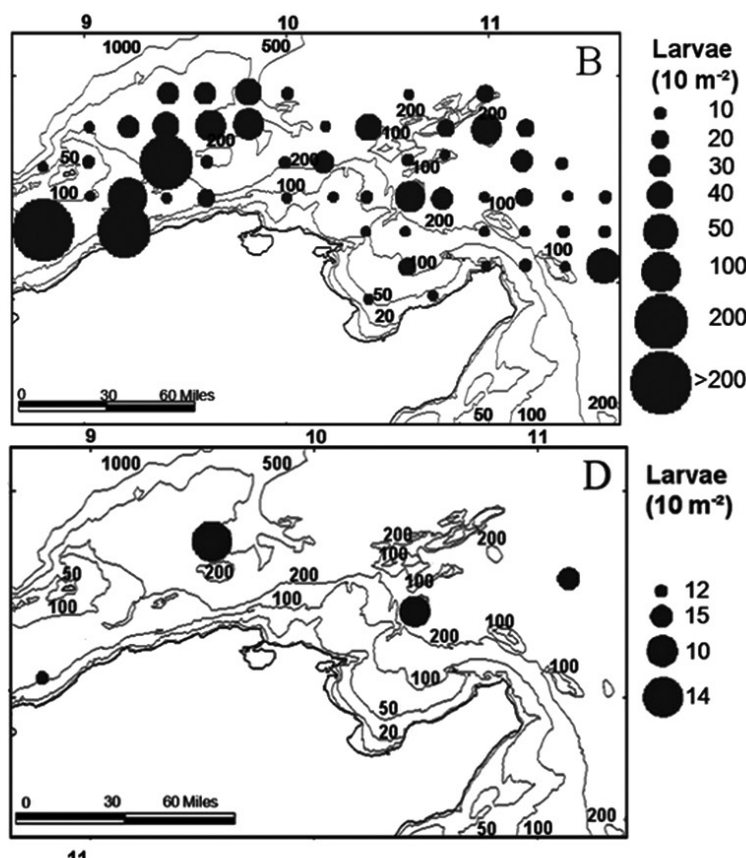

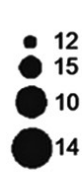 \\ 12}




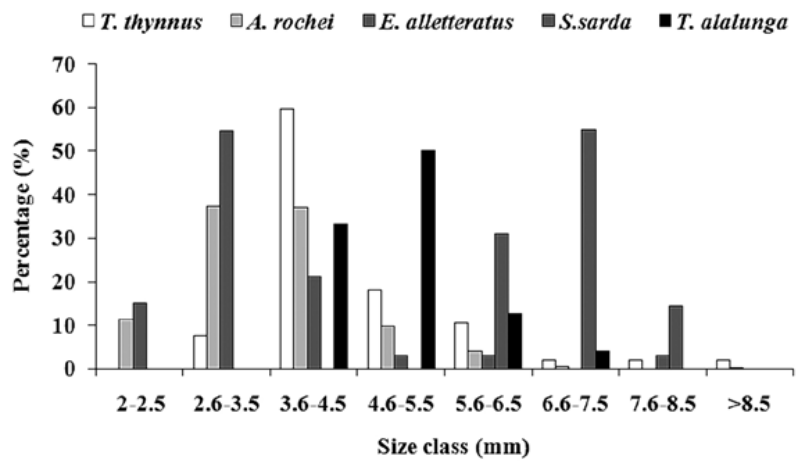

Fig. 9. - Histogram showing the different size class of tuna species.

Table 2. - Number and minimum, maximum and mean standard lengths $(\mathrm{mm})$ of tuna larvae, by species.

\begin{tabular}{lccccc}
\hline Species & Number & Min & Max & Mean & 土SD \\
\hline T. thynnus & 193 & 2.7 & 8.1 & 4.3 & 1 \\
A. rochei & 1531 & 2.16 & 9.4 & 3.6 & 0.94 \\
E. alletteratus & 66 & 2.24 & 7.85 & 3.5 & 1.11 \\
S. sarda & 10 & 5.8 & 8.1 & 6.62 & 0.79 \\
T. alalunga & 6 & 4 & 6.6 & 4.9 & 1 \\
\hline
\end{tabular}

and at the entrance of the Gulf of Tunis, and at four oceanic stations (Fig. 8C). Their larvae abundances ranged between 0.7 and 16.14 larvae $/ 10 \mathrm{~m}^{2}$ (mean values $=4.65 \pm 4.2$ larvae $/ 10 \mathrm{~m}^{2}(\mathrm{SD})$ ).

Atlantic bonito and albacore larvae were occasionally collected. They showed a very scattered distribution over the study area (Fig. 8D, E), with mean abundances of 3.6 and 1.7 larvae $/ 10 \mathrm{~m}^{2}$, respectively.

\section{Larval population structure}

Size distributions of bullet tuna and Atlantic black skipjack larvae show that more than $60 \%$ of individuals measured between 2 and $3.5 \mathrm{~mm}$ (Fig. 9), corresponding to 2 and 4 days old for the bullet tuna (LaízCarrión et al. 2013) and 1 to 3 days old for the Atlantic black skipjack (Allman and Grimes 1998), with a mean length of $3.6 \pm 0.94 \mathrm{~mm}(\mathrm{SD})$ and $3.5 \pm 1.11 \mathrm{~mm}(\mathrm{SD})$, respectively (Table 2 ).
By contrast, the standard length frequency distribution of Atlantic bonito and albacore tuna shows the absence of individuals smaller than $3.5 \mathrm{~mm}$, about one day old (Garcia et al. 2006, Sarropoulou et al. 2014). Most Atlantic bonito larvae were between 6.6 and 7.5 $\mathrm{mm}$ ( 5 to 7 days old [Sarropoulou et al. 2014]) and most albacore larvae were between 4.6 and $5.5 \mathrm{~mm}$ (10 to 14 days old [Garcia et al. 2006]). These results explain the high average sizes calculated for these two species: $6.62 \pm 0.79 \mathrm{~mm}$ and $4.9 \pm 1 \mathrm{~mm}$, respectively.

Atlantic bluefin tuna larvae size ranged between 2.7 and $8.1 \mathrm{~mm}$ ( 1 to 15 days old [Garcia et al. 2006]), with an average of $4.3 \pm 1 \mathrm{~mm}$. The majority of Atlantic bluefin tuna larvae (58\%) were within the 3.6-4.5 mm standard length size class (Table 2), between 2 to 4 days old (Garcia et al. 2006).

\section{Environmental characterization of larval habitats}

Only the three most abundant and widespread species were considered for characterizing larval habitats: the bullet tuna, the Atlantic bluefin tuna and the Atlantic black skipjack. The mean temperature of the positive stations was similar for all three tuna species. The highest was for the Atlantic black skipjack $\left(24.57 \pm 0.6^{\circ} \mathrm{C}\right.$ [SD]), followed by the bullet tuna $\left(24.48 \pm 0.63^{\circ} \mathrm{C}[\mathrm{SD}]\right)$ and the Atlantic bluefin tuna $\left(24.15 \pm 0.49^{\circ} \mathrm{C}\right.$ [SD]) (Table 3 ). Results from the quotient analysis indicated that all species showed a preferential association for SST of $25^{\circ} \mathrm{C}$ (Fig. 10A).

During this survey, Atlantic bluefin tuna larvae were caught at stations with SST ranging between 23.5 and $25^{\circ} \mathrm{C}$, showing significant preferences for 24 and $25^{\circ} \mathrm{C}$ values. A clear unsuitability was observed for warmer surface temperatures over $25^{\circ} \mathrm{C}$. Larvae of bullet tuna and Atlantic black skipjack showed a preferential association for waters with warmer surface temperature, between 25 and $26^{\circ} \mathrm{C}$.

Tuna larvae were mainly caught in water with mixed sea surface salinity, with values not exceeding 37.5. In saltier waters, over 37.6, no Atlantic bluefin tuna larvae were caught. The two other species also showed a

Table 3. - Basic statistics for some environmental variables recorded at the positive stations where larvae of the three most abundant tuna

\begin{tabular}{|c|c|c|c|c|c|c|c|}
\hline & & Temperature & Salinity & Turbidity & Chlorophyll $a$ & Zooplankton & Depth \\
\hline \multirow[t]{4}{*}{ T. thynnus } & Min & 23.16 & 36.9 & 0.01 & 0.12 & 0.55 & 49 \\
\hline & $\operatorname{Max}$ & 24.8 & 37.4 & 1.37 & 0.2 & 30.8 & 738 \\
\hline & Mean & 24.15 & 37.04 & 0.7 & 0.187 & 14.93 & 296 \\
\hline & $\pm \mathrm{SD}$ & 0.49 & 0.14 & 0.44 & 0.038 & 9.44 & 188 \\
\hline \multirow[t]{4}{*}{ A. rochei } & Min & 23 & 36.9 & 0.09 & 0.119 & 1.7 & 33 \\
\hline & Max & 26.2 & 37.8 & 1.21 & 0.274 & 61 & 787 \\
\hline & Mean & 24.48 & 37.12 & 0.64 & 0.201 & 23 & 257.6 \\
\hline & $\pm \mathrm{SD}$ & 0.63 & 0.21 & 0.43 & 0.039 & 15.38 & 175.3 \\
\hline \multirow{4}{*}{ E. alletteratus } & Min & 23.6 & 36.9 & 0.09 & 0.12 & 0.55 & 33 \\
\hline & Max & 25.8 & 37.7 & 1.88 & 0.255 & 61 & 738 \\
\hline & Mean & 24.57 & 37.13 & 1.15 & 0.198 & 29.48 & 264.5 \\
\hline & $\pm \mathrm{SD}$ & 0.61 & 0.21 & 0.47 & 0.046 & 16.51 & 187.6 \\
\hline \multirow[t]{4}{*}{ T. alalunga } & Min & 23.9 & 37 & 0.46 & 0.17 & 5.3 & 134 \\
\hline & Max & 24.9 & 37.3 & 1.25 & 0.22 & 20.6 & 465 \\
\hline & Mean & 24.36 & 37.1 & 0.98 & 0.19 & 12.76 & 326.7 \\
\hline & $\pm \mathrm{SD}$ & 0.5 & 0.17 & 0.45 & 0.026 & 7.68 & 172 \\
\hline \multirow[t]{4}{*}{ S. sarda } & Min & 23.9 & 36.9 & 0.82 & 0.175 & 8.45 & 108 \\
\hline & Max & 25.1 & 37.3 & 1.25 & 0.189 & 51.66 & 472 \\
\hline & Mean & 24.45 & 37.05 & 1.01 & 0.179 & 31.25 & 331.2 \\
\hline & $\pm \mathrm{SD}$ & 0.515 & 0.17 & 0.22 & 0.006 & 17.7 & 173.3 \\
\hline
\end{tabular}



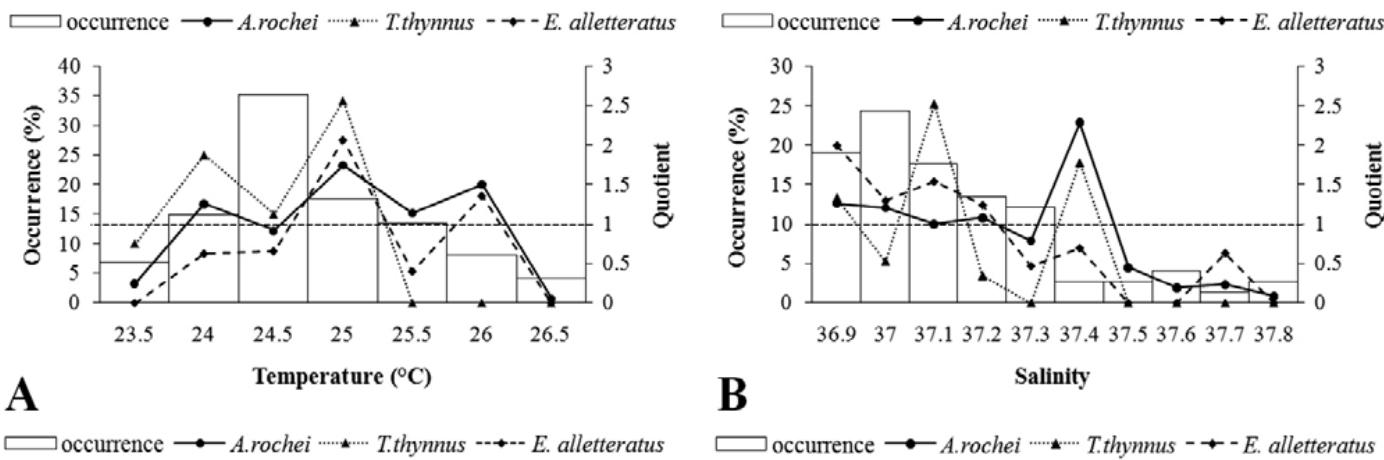

B

Salinity

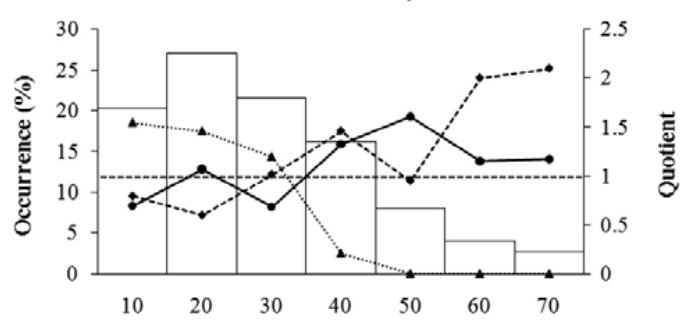

C

Zooplankton dry weight ( $\left.\mathrm{mg} \mathrm{m}^{-3}\right)$

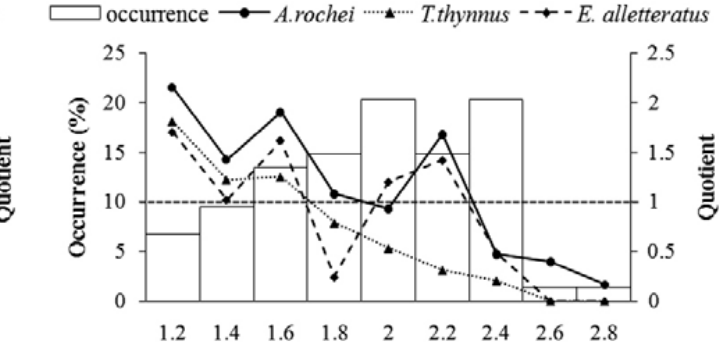

D

Chlorophyll a $\left(\mathrm{mg} \mathrm{m}^{-3}\right)$

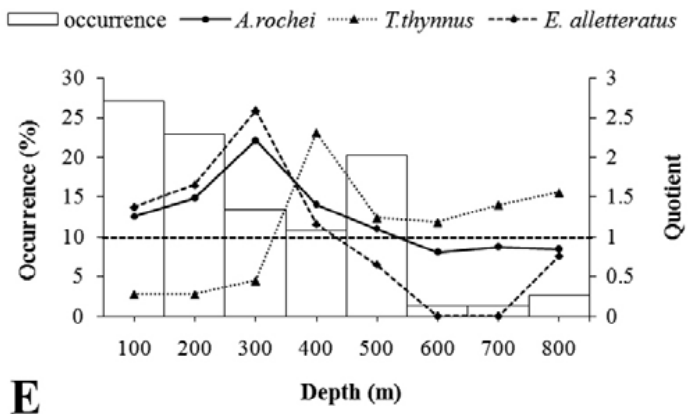

Fig. 10. - Results of Quotient analysis for three tuna species; Atlantic bluefin tuna (Thunnus thynnus), bullet tuna (Auxis rochei) and Atlantic black skipjack (Euthynnus alletteratus), with respect to sea surface temperature (A), sea surface salinity (B), zooplankton biomass (C), chlorophyll $a$ concentration (D) and depth (E). Dotted lines represent confidence intervals.

clear unsuitability for these saltier waters (Fig. 10B). The maximum salinity value where Atlantic bluefin tuna larvae were found was 37.4, while bullet tuna and Atlantic black skipjack larvae were found at maximum salinities of 37.8 and 37.7, respectively.

All tuna species were found over a wide range of depths, between 33 and $790 \mathrm{~m}$. Larvae of small tuna (bullet tuna and Atlantic black skipjack) were mainly caught in shallower waters near to the shelf break, between 200 and $400 \mathrm{~m}$. Contrastingly, Atlantic bluefin tuna larvae showed a preferential association with deeper stations, between 400 and $800 \mathrm{~m}$ (Fig. 10E).

At the positive stations for tuna larvae, chlorophyll $a$ concentration and zooplankton biomass ranged from 0.12 to $0.27 \mathrm{mg} \mathrm{m}^{-3}$ and from 0.55 to $61 \mathrm{mg} \mathrm{m}^{-3}$, respectively. Bullet tuna larvae were found in a wide range of chlorophyll $a$ values, between 0.12 and 0.27 $\mathrm{mg} \mathrm{m} \mathrm{m}^{-3}$, whereas Atlantic bluefin tuna and Atlantic black skipjack larvae were more frequent in waters with values ranging from 0.12 to $0.16 \mathrm{mg} \mathrm{m}^{-3}$.

Atlantic bluefin tuna larvae showed a preference for lower zooplankton dry weight values, between 10 and $30 \mathrm{mg} \mathrm{m}^{-3}$ (Fig. 10C), whereas bullet tuna and Atlantic black skipjack were mainly found at stations with higher zooplankton biomass, from 40 to $70 \mathrm{mg} \mathrm{m}^{-3}$.
Finally, tuna larvae, particularly those of Atlantic bluefin tuna, showed a preference for waters with lower DIN and orthophosphate concentration values, from 0.45 to $2.5 \mu \mathrm{mol} \mathrm{l}^{-1}$ for nitrate, from 0.06 to $0.31 \mu \mathrm{mol}$ $1^{-1}$ for nitrite, from 0.09 to $0.58 \mu \mathrm{mol}^{-1}$ for ammonium and from 0.05 to $0.2 \mu \mathrm{mol} 1^{-1}$ for orthophosphate.

\section{DISCUSSION}

Considering their importance for population dynamics, early life stages of tuna species in the southern part of the Mediterranean have not received the attention they deserve from the scientific community. As a result, detailed knowledge about spawning locations and larval habitats for tuna species have been mainly restricted to the northern and central sectors of the Mediterranean Sea (Alemany et al. 2010, Reglero et al. 2012).

The high concentration of tuna spawners during the spawning period in Tunisian waters suggested that this area could be another potential spawning ground for these species (Hattour 2000), but until recently the scarcity of ichthyoplankton studies prevented this hypothesis from being confirmed and limited the recognition and characterization of tuna spawning locations (Koched et al. 2012). 
The presence of tuna larvae in Tunisian waters has only recently been demonstrated through two previous ichthyoplankton surveys carried out on the eastern coasts of Tunisia (Koched et al. 2012) and in the Gulf of Gabes (Koched et al. 2013). These two studies suggested that Tunisian waters are one of the important spawning areas of these species in the Mediterranean. The present study allows us to conclude definitively that most tuna species inhabiting the Mediterranean Sea, including Atlantic bluefin tuna, also spawn along the whole Tunisian coast.

Larvae of five tuna species were identified in this area; the Atlantic bluefin tuna, the bullet tuna, the Atlantic black skipjack, the Atlantic bonito and the albacore. Larvae of the same species, except the Atlantic bonito, have also been collected in other areas of Tunisian waters (Koched et al. 2012, 2013, 2015, Zarrad et al. 2013) and in the central and eastern part of the Mediterranean (Garcia et al. 2005, Tsuji et al. 1997, Oray and Karakulak 2005).

The high concentrations of Atlantic bluefin tuna larvae at the offshore stations may be clear evidence that this species tends to avoid the productive coastal waters and prefers the offshore oligotrophic waters, in agreement with earlier ichthyoplankton studies carried out in Tunisia (Koched et al. 2012, 2013, 2015) and in other areas of the Mediterranean (Oray and Karakulak 2005, Alemany et al. 2010).

This preference for the offshore deep waters could be the consequence of adult distribution, since Atlantic bluefin tuna is a large tuna that usually inhabits offshore and deep waters, unlike small tunas such as bullet tuna and Atlantic black skipjack, which prefer to live in inshore waters (Alemany et al. 2010). However, in contrast to previous studies carried out in Tunisian waters (Koched et al. 2012, 2013), individuals of Atlantic bluefin tuna larvae were also found at some coastal stations. This maybe the consequence of the narrowness of the continental shelf, which should favour the presence of Atlantic bluefin tuna larvae near the coasts, due to both presence of spawners closer to the shoreline and larval drift from slope to shelf areas.

The highest abundance of tuna larvae was recorded near the island of Galite, surrounded by oligotrophic and shallow waters (not exceeding $100 \mathrm{~m}$ ). The high tuna larvae density around islands has also been reported in other areas of the Mediterranean, such as the Balearic archipelago (Alemany et al. 2006, 2010), and in the Pacific ocean, close to French Polynesia (Leis et al. 1991) and Hawaiian islands (Miller 1979).

Several hypotheses have been proposed to explain this association around islands. In the case of oceanic islands, Doty and Oguri (1956) hypothesized that this could be due to the "island mass effect", stating that increased plankton biomass near islands may result in an increase of fish larvae biomass, including tuna larvae, through enhanced survival. Another hypothesis was put forward by Boehlert and Mundy (1994), who supposed that this high concentration is the result of the aggregation of spawners near islands for feeding. However, these hypotheses do not seem applicable to Mediterranean islands, since waters surrounding them are even more oligotrophic than those closer to the neighbouring mainland coasts and, at least in the case of Atlantic bluefin tuna, adult fishes migrate into the Mediterranean from much more productive Atlantic areas for spawning, not for feeding. Our present results should be in accordance with the hypotheses from Alemany et al. (2010) and Reglero et al. (2012), who suggested that precisely the oligotrophic character of waters surrounding some Mediterranean islands, such as those of the Balearic archipelago, should increase the tuna larvae survival rates due to the scarcity of predators and competitors, particularly in the upper mixed layer of the water column that tuna larvae inhabit. Moreover, these authors hypothesized that the complex hydrodynamic scenario resulting from the interaction of inflowing recent Atlantic surface waters and resident waters modulated by the islands' topography, characterized by the presence of mesoscale hydrographic features such as fronts and eddies, would constitute a strong retention zone and a favourable habitat for larval survival, enhancing encounter rates between tuna larvae and potential preys (Reglero et al. 2012). The unsuitability of Atlantic bluefin tuna larvae of more productive coastal waters has also been reported in the Gulf of Mexico (Muhling et al. 2013). These hypotheses were reinforced by the results of Koched et al. (2013) in the Gulf of Gabes, which revealed the absence of Atlantic bluefin tuna larvae near the islands of Kerkennah and Djerba, placed on the wide continental shelves characterized by shallow depths and high trophic conditions.

Larval size distributions of bullet tuna and Atlantic black skipjack show that most individuals are small, corresponding to yolk-sack and preflexion larvae (considering available information on larval growth [Allman and Grimes 1998, Laíz-Carrión et al. 2013]), which indicates that spawning activity is taking place within the study area. On the contrary, the absence of very small Atlantic bluefin tuna larvae, less than one day old, suggests that most of these larvae could be advected from neighbouring and deeper areas, and also that sampling was carried out after the spawning peak of the species in the area. Previous studies in the Mediterranean have shown that Atlantic bluefin tuna show preference for deeper areas, more than $1000 \mathrm{~m}$ depth, to spawn (Alemany et al. 2010, Reglero et al. 2012). The fact that the highest abundances of Atlantic bluefin tuna within this study were found around Galite island, the place within the study area closest to the $1000 \mathrm{~m}$ isobaths, would support this hypothesis. Regarding spawning time, considering that Atlantic bluefin tuna spawning in Tunisian water starts in June and that spawning activity for a given individual lasts around 20 days (Hattour 2000), the fact that our survey was carried out entirely in July diminishes the probability of capturing the smallest larvae.

On the other hand, despite its importance in the Tunisian fisheries, with $37.1 \%$ of total small tuna landing (Hattour 2009), Atlantic bonito larvae were considerably less abundant than most of the other tuna species larvae. In fact, only 10 larvae, with a mean abundance of 7.75 larvae $/ 10 \mathrm{~m}^{2}$ at positive stations, were caught in 
the sampled area. Previous studies in Tunisian waters have not succeeded in capturing Atlantic bonito larvae (Koched et al. 2012, 2013), even though these surveys were carried out during the spawning peak of this species (Hattour 2000). These results suggest that Tunisian waters may not be a preferential spawning sector for the Atlantic bonito. Therefore, we can consider that this species uses Tunisian waters as a passage area to other spawning sectors.

This hypothesis is reinforced by the absence of small larvae in our samples. It is worth pointing out that in other Mediterranean areas under the influence of recent surface Atlantic waters, such as the Balearic Islands, the presence of Atlantic bonito larvae is also only occasional (Alemany et al. 2010), whereas they are more abundant on Spanish mainland coasts where resident waters dominate (Sabatés and Recasens 2001). Spawning migration of Atlantic bonito has already been demonstrated from the Adriatic and Aegean Seas to the Black Sea, considered as the most important spawning area for this species in the Mediterranean (Demir 1963, Ivanov and Beverton 1985).

Albacore tuna larvae were also caught in low numbers, as occurred in previous studies carried out in other regions of Tunisia (northeastern coasts and the Gulf of Gabes) (Koched 2013, Koched et al. 2011). This species has been cited previously only once in Tunisian waters, by Bradai et al. (2004), and it has not yet been recorded among the Tunisian landings. These facts suggest that Tunisian waters could be considered as a passage area, where some genitors release their eggs during their spawning migrations to neighbouring main spawning areas, such as the Ionian Sea (Piccinetti and Piccinetti-Manfrin 1993). Considering larval sizes and numbers as well as the hydrodynamic scenario, albacore larvae could have been advected from the Ionian Sea instead of being spawned within the surveyed area. However, the scarcity of albacore larvae is at least also partly a result of the timing of the reproductive activity of this species, which peaks later in the summer season (Alemany et al. 2006, 2010).

Larval spatial distribution indicates that bullet tuna larvae are more widely distributed over the study area than the larvae of other tuna species. This broad distribution suggests that this species spawns over the entire continental shelf and the shelf break, as also reported in the earlier works carried out in Tunisian waters (Koched et al. 2012, 2013) and in other Mediterranean regions, such as the Balearic Sea (Alemany et al. 2010), the Catalan coasts (Sabatés and Recasens 2001) and the Levantine Sea (Oray and Karakulak 2005).

The wide distribution of bullet tuna larvae is coherent with their preference for wider ranges of temperature and of other environmental variables (salinity, chlorophyll $a$, zooplankton biomass, DIN and depth) (Fig. 10) compared with the other tuna larvae. This tolerance in relation to environmental conditions also explains the longer spawning season of this species (Alemany et al. 2010, Torres et al. 2011).

Atlantic black skipjack larvae distribution was more coastal than that of other tuna species, showing a preference for higher chlorophyll $a$ and zooplankton biomass concentrations, which indicate that this species tends to avoid the open sea and prefers to spawn in more productive waters over the continental shelf. This conclusion is in agreement with available knowledge about the reproductive strategies of this species (Koched et al. 2012, 2013).

All larvae of the tuna species considered in this study show a clear preference for the salinity values corresponding to mixed waters resulting from the interaction between the surface waters of recent Atlantic origin and resident waters, not exceeding values of 37.4 , and the unsuitability of saltier resident waters. This preferential association, especially in the case of the Atlantic bluefin tuna larvae, is probably a direct consequence of the influence of the dynamics of recent Atlantic waters inflowing from Atlantic Ocean to the Mediterranean Sea on the adult tuna migration patterns. Previous studies carried out by Sarà (1964, 1973) confirm that Atlantic bluefin tuna spawners, and probably those of other tuna species, reach the northern coasts of Tunisia following the surface recent Atlantic waters input, usually flowing outside the shelf break (Millot 1987). This observation has also been made in the other regions of Tunisia (Koched et al. 2012, 2013), in the Balearic Sea (Torres et al. 2011, Reglero et al. 2012) and in the Levantine Sea (Oray and Karakulak 2005). On the other hand, the clear association with SST around $25^{\circ} \mathrm{C}$ suggests that temperature is also an important driver of tuna spawning.

The observed preference of large tuna larvae (Atlantic bluefin tuna and albacore) for lower SST in comparison with the larvae of smaller tunas, where mainly encountered at the stations characterized by higher temperature, is probably the direct consequence of their spatial distribution. The same observation was made in previous studies carried out in other areas of Tunisian waters (Koched et al. 2012, 2013) and in the Balearic Sea (Alemany et al. 2010).

\section{CONCLUSIONS}

Like other Tunisian waters, those located off the northern of Tunisian coasts constitute an important spawning area for several tuna species, such as Atlantic bluefin, Atlantic black skipjack and bullet tuna. Horizontal bluefin tuna larvae distribution indicates a preference for offshore and oligotrophic waters, whereas bullet, skipjack and Atlantic black skipjack larvae were mainly encountered in more productive and shallow areas.

The low abundance of Sarda sarda and Thunnus alalunga larvae in our samples, as well as the absence of small yolk sac larvae of these species, indicate that northern Tunisian waters are not an important spawning area for these two species. In the case of Thunnus alalunga this scarcity is also attributable to the mismatch between sampling period and spawning peak. However, considering the information about presence of T. alalunga larvae in other Mediterranean regions, their proportion should have been higher if Tunisian waters were a preferential spawning area for the species. 


\section{ACKNOWLEDGEMENTS}

This work was carried out by the National Institute of Science and Technology of the Sea (INSTM). We would like to thank all members of the Hannibal crew for providing facilities during this study, and particularly for their meaningful help during the sampling time. We also thank the other scientists and technicians who participated in this survey.

\section{REFERENCES}

Alemany F. 1997. Ictioplancton del Mar Balear. Ph.D. thesis, Univ. Illes Balears, Palma de Mallorca, $496 \mathrm{pp}$

Alemany F., Deudero S., Morales-Nin B., et al. 2006. Influence of physical environmental factors on the composition and horizontal distribution of summer larval fish assemblages off Mallorca Island (Balearic archipelago, Western Mediterranean). J. Plankton Res. 28: 473-487. http://dx.doi.org/10.1093/plankt/fbi123

Alemany F., Quintanilla L., Velez-Belchi P., et al. 2010. Characterization of spawning hábitat of Atlanric bluefin tuna and related species in the Balearic Sea (western Mediterranean). Prog. Oceanogr. 86: 21-38. http://dx.doi.org/10.1016/j.pocean.2010.04.014

Allman R.J., Grimes C.B. 1998. Growth and mortality of little tunny (Euthynnus alleteratus) larvae off the Mississippi river Plume and Panama city, Florida. Bull. Mar. Sci. 62: 189-197.

Astraldi M., Gasparini G.P., Sparnocchia S. 1998. Water masses and seasonal hydrographic conditions in the Sardinia Sicily Tunisia region. Rapp. Comm. int. Mer Médit. 35: 122-123.

Ayari R., Afli A. 2003. Bionomie benthique du petit golfe de Tunis. Bull. Inst. Nat. Sci. Technol. Mer 30: 79-90.

Ben Souissi J., Golani D., Mejri H., et al. 2006. On the occurrence of Scomberomorus commerson Lacepède, 1800 (Osteichthyes: Scombridae) off northern Tunisia (Central Mediterranean). Cah. Biol. Mar. 47: 215-218.

Boehlert G.W., Mundy B.C. 1994. Vertical and onshore-offshore distributional patterns of tuna larvae in relation to physical habitat features. Mar. Ecol. Prog. Ser. 107: 1-13. http://dx.doi.org/10.3354/meps107001

Bradai M.N., Quignard J.P., Bouain A., et al. 2004. Ichtyofaune autochtone et exotique des côtes tunisiennes: recensement et biogéographie. Cybium 28(4): 315-328.

Cavallaro G., Manfrin G., Lo Duca G., et al. 1997. The presence of tuna larvae in the straits of Messina. ICCAT. Collect. Vol. Sci. Pap. 46(2): 222-224.

Clarke K.R., Gorley R.N. 2006. PRIMER v6: User Manual/Tutorial. PRIMER-E, Plymouth.

Demir M. 1963. Synopsis of biological data on bonito, Sarda sarda (Bloch). FAO Fish. Rep. 6: 101-129.

Dicenta A. 1975. Identificación de algunos huevos y larvas de túnidos en el Mediterráneo. Bol. IEO. 198: 1-22.

DGPA 2013. Annuaire des statistiques de la pêche et d'aquaculture en Tunisie, Tunis, $114 \mathrm{pp}$.

Dolédec S., Chessel D. 1989. Rythmes saisonniers et composantes stationnelles en milieu aquatique II- Prise en compte et élimination d'effets dans un tableau faunistique. Acta Oecol- Oec. Gen. 10: 207-232

Doty M.S. Oguri M. 1956. The island mass effect. J. Conseil. 22: 33-37.

Fromentin J.M., Powers J.E. 2005. Atlantic bluefin tuna: population dynamics, ecology, fisheries and management. Fish and Fisheries. 6(4): 281-306. http://dx.doi.org/10.1111/j.1467-2979.2005.00197.x

Frontier S. 1973. Etude statistique de la dispersion du zooplancton. J. Exp. Biol. Ecol. 12 : 229-262.

García A., Alemany F., Velez-Belchí P., et al. 2003. Bluefin and frigate tuna spawning off the Balearic archipelago in the environmental conditions observed during the 2002 spawning season. ICCAT. Collect. Vol. Sci. Pap. 55: 1261-1270.

Garcia A., Alemany F., De La Serna J.M., et al. 2005. Preliminary results of the 2004 bluefin tuna larval surveys off different Mediterranean sites (Balearic archipelago, Levantine sea and the Sicilian channel). ICCAT. Collect.Vol. Sci. Pap. 58: 1420-1428.

Garcia A., Cortés D., Ramirez T., et al. 2006. First data on growth and nucleic acid and protein content of fieldcaptured Mediter- ranean bluefin (Thunnus thynnus) and albacore (Thunnus alalunga) tuna larvae: a comparative study. Sci Mar. 70: 67-78.

Grasshoff K. 1983. Determination of nitrate. In: Grasshoff K., Ehrhardt M., Kremling K. (eds), Methods of seawater analysis. Weinheim, Verlag Chemie, pp. 143.

Hattour A. 2000. Contribution à l'étude des poissons pélagiques des eaux tunisiennes. Ph.D. thesis. Univ. Tunis II, $343 \mathrm{pp}$.

Hattour A. 2007. Annual report of Tunisia. In: Report for biennial period 2006-07. Part I (2006). Vol. 3. Annual Reports. Madrid, International Commission for the Conservation of Atlantic Tunas, pp. 116-132.

Hattour A. 2009. Les thons mineurs tunisiens: étude biologiques et pêche, ICCAT. Collect. Vol. Sci. Pap. 64(7): 2230-2271.

Hsieh C.H., Reiss C.S., Hunter J.R. et al. 2006. Fishing elevates variability in the abundance of exploited species. Nature 443 : 859-862. http://dx.doi.org/10.1038/nature05232

ICCAT. 2009. Report of the Standing committee on Research and Statistics (SCRS) Madrid, Spain, October 5-9, 2009. ICCAT Report 2008-2009. 2: 1-270.

ICCAT. 2010. Report for biennial period 2008-2009. International commission for the conservation of Atlantic tunas. Vol. 2, $354 \mathrm{pp}$.

ICCAT. 2014. Report for biennial period 2012-2013. International commission for the conservation of Atlantic tunas. Vol. 2, $343 \mathrm{pp}$.

Isari S., Fragopoulu N., Somarakis S. 2008. Interranual variability in horizontal patterns of larval fish assemblages in the northeastern Aegean Sea (eastern Mediterranean) during early summer. Estuar. Coast. Shelf Sci. 79(4): 607-619. http://dx.doi.org/10.1016/i.ecss.2008.06.001

Ivanov L., Beverton R.J.H. 1985. The fisheries research of the Mediterranean. Part II - Black Sea. Etud. Rev. CGPM. 60: 135 pp.

Koched W. 2013. Distribution des larves des thonidés des eaux tunisiennes: relations avec les paramètres environnementaux et inventaire des larves téléostéens associées. Ph.D. thesis. Univ. Monastir, $230 \mathrm{pp}$.

Koched W.. Hattour A., Saïd K. 2011. Les larves de poissons téléostéens le long des côtes Est tunisiennes : distribution et abondance. Bull. Inst. Nat. Sci. Technol. Mer 38: 29-39.

Koched W., Hattour A., Alemany F., et al. 2012. Distribution of tuna larvae in Tunisian east coasts and its environmental scenario. Cah. Biol. Mar. 53: 505-515.

Koched W., Hattour A., Alemany F., et al. 2013. Spatial distribution of tuna larvae in the Gulf of Gabes (Eastern Mediterranean) in relation with environmental parameters. Med. Mar. Sci. 14(1): $5-14$. http://dx.doi.org/10.12681/mms.314

Koched W., Alemany F., Ben Ismail S., et al. 2015. Environmental conditions influencing the larval fish assemblage during summer in the Gulf of Gabes (Tunisia: South central Mediterranean). Med. Mar. Sci. 16(3): 666-681.

Laiz-Carrión R., Quintanilla J.M., Pérez-Torres A., et al. 2013. Hydrographic patterns conditioning variable trophic pathways and early life dynamics of bluefin tuna larvae (Auxis rochei) in the Balearic Sea. Mar. Ecol. Prog. Ser. 475: 203-212. http://dx.doi.org/10.3354/meps10108

Lebart L., Morineau A., Fénelon J.P. 1982. Traitement des données statistiques: méthodes et programmes. Paris, Dunod, $510 \mathrm{pp}$

Leis J.M., Trnsky T., Harmelin-Vivien M., et al. 1991. The larvae of Indo-Pacific coastal fishes: High concentration of tuna larvae (Pisces: Scombridae) in near reef waters of French Polynesia (Society and Tuamotu Islands). Bull. Mar. Sci. 48: 150-158.

Lorenzen C.J. 1967. Determination of chlorophyll and pheopigments: spectrophotometric equations. Limnol. Oceanogr. 12: 343-346.

Lovegrove T. 1966. The determination of the dry weight of plankton and the effect of various factors of the values obtained. In: Barnes H., (eds), Some contemporary studies in marine science, pp. 429-467. London.

McKeown B.A. 1984. Fish migration. London, Croom Helm, 224 pp.

Miyake P.M., de la Serna J.M., di Natale A., et al. 2003. General review of Atlantic bleufin tuna farming in the Mediterranean area. ICCAT. Collect. Vol. Sci. Pap. 55: 114-124.

Miller J.M. 1979. Nearshore abundance of Tuna (Pisces: Scombridae) larvae in the Hawaiian Islands. Bull. Mar. Sci. 29: 19-26.

Millot C. 1987. Circulation in the Western Mediterranean Sea. Oceanol. Acta. 10: 143-149.

Morote E., Olivar M.P., Pankhurst P.M., et al. 2008. Trophic ecology of bullet tuna Auxis rochei larvae and ontogeny of feedingrelated organs. Mar. Ecol. Prog. Ser. 353: 243-254. 
http://dx.doi.org/10.3354/meps07206

Muhling B.A., Reglero P., Ciannelli L., et al. 2013. Comparison between environmental characteristics of larval bluefin tuna Thunnus thynnus habitat in theGulf of Mexico and western Mediterranean Sea. Mar. Ecol. Prog. Ser. 486: 257-276. http://dx.doi.org/10.3354/meps10397

Oray I., Karakulak S. 2005. Further evidence of spawning of bluefin tuna (Thunnus thynnus L., 1758) and the tuna species (Auxis rochei Ris., 1810, Euthynnus alletteratus Raf., 1810) in the eastern Mediterranean Sea: preliminary results of TUNALEV larval survey in 2004. J. Apll. Ichtyol. 21: 236-240. http://dx doi.org/10.1111/j.1439-0426.2005.00658.x

Piccinetti C., Piccinetti-Manfrin G. 1993. La riproduzione dei tunnidi in Mediterraneo. Biol. Mar. Medit. 1: 325-328.

Piccinetti C., Piccinetti-Manfrin G., Soro S. 1997. Résultats d'une campagne de recherche sur les larves de thonidés en Méditerranée. ICCAT. Collect. Vol. Sci. Pap. 46(2): 207-214.

Piccinetti C., Di Natale A., Arena P. 2013. Eastern bluefin tuna (Thunnus thynnus, L.) reproduction and reproductive areas and season. ICCAT. Collect. Vol. Sci. Pap. 69(2): 891-912.

Reglero P., Ciannelli L., Alvarez-Berastegui D., et al. 2012. Geographically and environmentally driven spawning distributions of tuna species in the western Mediterranean Sea. Mar. Ecol. Prog. Ser. 463: 273-284. http://dx.doi.org/10.3354/meps09800

Sabatés A., Recasens L. 2001. Seasonal distribution and spawning of small tunas, Auxis rochei (Risso) and Sarda sarda (Bloch) in the northwestern Mediterranean. Sci. Mar. 65(2): 95-100.

Santamaría N., Acone F., Deflorio M., et al. 2000. Età ed accrescimento in giovani di Tombarello (Auxis rochei Risso, 1810) nei mari meridionali italiani. Biol. Mar. Med. 8: 765-770.

Sarà R. 1964. Data, observations and comments on the occurrence, behaviour, characteristics and migrations of tunas in the Mediterranean. Proceed. Techn. Papers, General Fisheries Council for the Mediterranean. 7: 371-388.

Sarà R. 1973. Sulla biología dei tonni (Thunnus thynnus L.) modelli di migrazione e di comportamento. Boll. Pesca Piscicult. Hidrobiol. 28: 217-243.

Sarropoulou E., Moghadam H.K., Papandroulakis N., et al. 2014. The Atlantic Bonito (Sarda sarda, Bloch 1793) Transcriptome and Detection of Differential Expression during Larvae Development. PLoS ONE 9(2): e87744.

http://dx.doi.org/10.1371/journal.pone.0087744

Satoh K. 2010. Horizontal and vertical distribution of larvae of $\mathrm{Pa}-$ cific bluefin tuna (Thunnus orientalis) in patches entrained in mesoscale eddies. Mar. Ecol. Prog. Ser. 404: 227-240. http://dx.doi.org/10.3354/meps08431

Somarakis S., Isari S., Machias A. 2011. Larval fish assemblages in coastal waters of central Greece: reflections of topographic and oceanographic heterogeneity. Sci. Mar. 75 (3): 605-618. http://dx.doi.org/10.3989/scimar.2011.75n3605

Twatwa N.M., van der Lingen C.D., Drapeau L., et al. 2005. Characterizing and comparing the spawning habitats of anchovy Engraulis encrasicolus and sardine Sardinops sagax in the southern Benguela upwelling ecosystem. Afr. J. Mar. Sci. 27: 487-499. http://dx.doi.org/10.2989/18142320509504107

Ter Braak C.J.F. 1986. Canonical correspondence analysis: a new eigenvector technique for multivariate direct gradient analysis. Ecology 67(5): 1167-1179. http://dx.doi.org/10.2307/1938672

Torres A.P., Reglero P., Balbin R., et al. 2011. Coexistence of larvae of tuna species and other fish in the surface mixed layer in the NW Mediterranean. J. Plank. Res. 33(12): 1793-1812. http://dx.doi.org/10.1093/plankt/fbr078

Tsuji S., Nishikawa Y., Segawa K., et al. 1997. Distribution and abundance of Thunnus thynnus larvae and their relation to the oceanographic condition in the Gulf of Mexico and the Mediterranean sea during may through august of 1994. ICCAT. Collect. Vol. Sci. Pap. 46: 161-176.

Yabe H., Uenayagi S., Watanabe H. 1966. Studies on the early life of Atlantic bluefin tuna Thunnus thynnus, and on the larva of the southern Atlantic bluefin tuna, Thunnus maccoyi. Nankai Region Fisheries Res. Lab. Rep. 23: 95-129.

Zarrad R., Alemany F., Rodriguez J.M., et al. 2013. Influence of summer conditions on the larval fish assemblage in the eastern coast of Tunisia (Ionian Sea, Southern Mediterranean). J. Sea Res. 76: 114-125.

http://dx.doi.org/10.1016/j.seares.2012.08.001 